\author{
Kęstutis Paulauskas* \\ Institute of International Relations and Political Science, University of Vilnius
}

\title{
NATO at 60: Lost in Transformation*
}

This article discusses NATO's evolution and prospects of its future developments. The article addresses internal tensions and dilemmas the Alliance's members may have to confront and overcome. The author contends that the process of preparation of the new strategic concept may have signaled a certain ideational crisis of NATO and its search for a new identity. NATO's "transformation" increasingly resembles an aimless process rather than a clear and to all allies unanimously acceptable raison d'etre. Robert Cooper's thesis of the international system consisting of pre-modern, modern and post-modern states is applied to explain NATO's problem of the strategic dissonance. Postmodern societies of the allies are increasingly less inclined to support military adventures beyond NATO's territory. NATO's operations often take place in pre-modern, anarchical environment of failed or failing states. Such missions require advanced technologies and a comprehensive, integrated civil-military approach. Many countries outside Europe and North America are 20th century-type modern nation-states, often undemocratic, like China and Russia. The latter country remains an important factor defining Alliance's identity within and in the international system. NATO, which seeks to become a progressive, forward looking Alliance of the 21st century, struggles to develop a dialogue with Russia on the most pertinent security problems in the post-sovereign and post-national European space. The new strategic concept will have to encompass all these apparently irreconcilable, "dissonant" elements. NATO no longer is a solely regional military block nor is it becoming a global political forum, which would be addressing all the most important international security problems. NATO is preparing to undertake both "most likely" operations, such as in Afghanistan and the most demanding, article 5 operations. It is possible that by focusing on light, expeditionary forces to be used in wars against asymmetrical, weak enemies the ability of the allies to wage conventional wars against near-peers will degrade. Russian war on Georgia has recently reminded that such wars in Europe are still likely. Lithuania's experience of NATO membership is mixed: some expectations were fulfilled, and some - not, but Lithuania has come a long way in seeking to become a more mature ally.

\section{Introduction}

NATO comes in many different guises - from the symbol of the triumph and glory of the Western community of democracies to an aggressive, expansionist military block with nefarious designs on other countries.

In the official Western narrative, NATO is the greatest and most successful military Alliance in (Western) history. NATO has outlasted the Warsaw Pact in the Cold War stand-off, NATO has pacified the Balkans and now is

\footnotetext{
${ }^{*}$ Dr. Kęstutis Paulauskas is a lecturer of the Institute of International Relations and Political Science of the University of Vilnius. In 2006-2009 he served as a Deputy Defence Advisor at the Lithuanian Delegation to NATO. Address for correspondence: Vokiečiu 10, LT-01130 Vilnius, Lithuania, tel.: + 370-5- 2514130, e-mail: kpaulauskas@gmail.com.

** Author thanks David Yost, Vaidotas Urbelis and Tomas Janeliūnas for valuable comments on earlier version of this article.
} 
bringing democracy and stability to the war-torn Afghanistan, as well as fighting pirates off Somali coast.

For a dozen Southern and Central European countries that emerged from the ruins of the communist dystopia, NATO is a dream-come-true of a secure and prosperous future, as well as an ultimate hedge against any possible revisionism of the post-Cold War borders in Europe. For a number of countries in the Balkans and Eastern Europe, it is an object of a similar aspiration and expectation (in some cases - a rather distant one).

For the Western European Allies, NATO has probably lost the existential appeal that it used to enjoy during the Cold War. For some, the Alliance has even become somewhat of a hurdle on the way of development of an autonomous European Security and Defence Policy. The NATO - EU relations are still locked in a "frozen conflict"1 ${ }^{11}$ an especially embarrassing feat for the 21 nations that are members of both.

For the Anglo-Saxon Allies - the United States and the United Kingdom, NATO serves as an extension of their global interests and ambitions (in the case of UK - those of the past). The concerns that the United States views NATO as a mere "toolbox" for its global adventures may have been exaggerated, but the waning commitment to NATO of some of the European Allies, can eventually be reciprocated by the policy makers in Washing D. C., to the detriment of European security.

Of course, there are also those who despise NATO, inside and outside the Alliance's borders. First, there is the "new enemy" - the "opposing forces" in Afghanistan. For the Taliban and Al Qaeda NATO is quite simply an evil spawn of the rotten, infidel West.

As for the "old enemy", NATO still plays a crucial role in Russia's strategic thinking. Russia's new strategic concept still considers NATO activities as threatening its security. Paradoxically, NATO's continued existence is probably more important for Moscow than for some of the Allies - "NATO" comes in as a handy tool that helps mobilize the discontented public in the face of an encroaching external enemy, an aggressive military Alliance, lurking at the borders to invade the Motherland.

Last but not least, there are the affluent Western European societies, which have long forgotten the horror of the world wars, and do not want to put their young men and women in harms way. The organized segments of those societies - various anti-war, anti-globalisation, anti-everything movements view NATO as a warmongering club of bloodthirsty generals that has to be disbanded immediately.

Most of these images and stereotypes are no doubt exaggerated, over simplistic and, ultimately, misleading. However, the share volume of different images indicates that NATO still remains a very important organisation with a global clout of appeal, recognition or despise. Within such a context, this

${ }^{1}$ Former NATO Secretary General Jaap de Hoop Scheffer used this label in a speech "NATO and the EU: Time for a New Chapter", on 29 Jan 2007. 
article tries to decipher what NATO is, what it is not and what it could be in the tumultuous beginning of the new millennium, as seen through (and caveated by) the perspective of an academic from a relatively new and a relatively small Ally.

This paper puts forward three interrelated propositions:

- NATO is (literally) an elderly Alliance, which is constantly trying to change and adapt to the rapidly evolving global environment. However, a clear purpose of NATO's existence may have been lost in the process of "continuous transformation".

- Although NATO undertakes ever more new missions, activities and partnerships, its political role has deflated over the past two decades because military power (albeit still important) is no longer the central element of international politics. Hence, NATO's urge to once again redefine its purpose.

- As a result, NATO is undergoing a sort of an identity crisis: complex dilemmas will have to be addressed and, in some cases, hard choices will have to be made.

The paper concludes with a chapter on the 5 years of membership experience of the 7 Allies that joined NATO in 2004. In this context, the key lesson is this: the trial phase is over. It is up to each Ally and its representatives in Brussels to work hard, fight for the agenda setting and, ultimately, die in the ditches for the interests that the given capital considers of national importance.

\section{The bloom and gloom of $60^{\text {th }}$ anniversary}

NATO, as a military alliance, is an agile organization. It has outlasted the Warsaw Pact in a 40-year long brinkmanship. It has survived the calls for its disbandment after the end of the Cold War. The Alliance has re-invented itself already twice by adopting a future-oriented Strategic Concept in 1991 and reviewing it in 1999 to reflect the lessons of the Balkan wars and prepare for the next century. In April 2009, NATO, 28-strong political and military Alliance, has celebrated its $60^{\text {th }}$ anniversary in Strasbourg/Kehl - a symbolic place of Franco-German rivalry and reconciliation. NATO at 60, however, seems to be short of ideas and suffer chronically from a case of strategic dissonance.

\subsection{A crisis of ideas?}

The festive mood of that summit has long subsided. NATO is facing a number of seemingly intractable issues. Some of them have always been there (e.g. the Soviet Union during the first 40 years, replaced by the cumbersome relationship with Russia during the latter 20), and some of them have been 
dictated by events: the Balkan wars during the 90s (NATO still finds itself in Kosovo); the 9/11 attacks on the US, which led to the ongoing war in Afghanistan; and the outburst of piracy off the coast of Horn of Africa, which constitutes the most recent addition to NATO's agenda.

Ever new challenges and ever more fluid global security environment prompted the Alliance to undertake a new revision of its overall strategy. The Allies seem to be struggling to define the $21^{\text {st }}$ century NATO and to agree its ultimate raison d'etre. The drafting process was entrusted to a group of twelve "wise men" headed by an even wiser woman Madeleine Albright, rather than the senior NATO committees which usually draft all key NATO documents the Senior Political Committee, the Executive Working Group or the Military Committee.

The drafting exercise was undertaken in an unprecedentedly transparent and all-inclusive way. It was launched on $7^{\text {th }}$ of July 2009 in a major conference in Brussels, attended by an eclectic gathering of "a broad range of representatives from Allied and Partner governments, NATO structures, international organizations, civil society, including parliaments, the corporate sector, NGOs, think tanks, academia and the media" ${ }^{2}$. This opening round was to be followed by a number of quasi-academic seminars, addressing various aspects of the concept.

The effort to solicit a broad range of views on NATO's strategic direction has clearly showcased what NATO no longer is - a closed, secretive military alliance. At the same, it might mean that the Allies are no longer certain about NATO's purpose and role in the global politics and are incapable of defining the future of NATO on their own. Albright's "inauguration" speech in the opening conference said all the right things to all the interested audiences. ${ }^{3}$ However, being nice to everyone does not necessarily make for a sound strategy.

One may wonder whether the Alliance's commendable exercise in transparency is masking the fact that the Allied leadership is running out of inspiring ideas that could capture the attention of the "google" generation. The first NATO secretary general Lord Ismay has famously described NATO's purpose as that of "keeping the Russians out, the Americans in, and the Germans down" - a phrase that sustained the strategic imagination of an entire generation. $09^{\prime}$ NATO is, of course, quite different from the $49^{\prime}$ NATO. Today, it is unimaginable that a secretary general of the new NATO could suggest such a catchy but politically sensitive or even incorrect slogan. A refreshing ignorance of politically incorrect language would probably prompt at something like "getting the Russians in, the Germans up and the American out" to describe the current state of affairs. Indeed, since the end of the Cold War, Germany has re-united, the American's have closed down most of their military installations

\footnotetext{
${ }^{2}$ NATO launches public debate on the Strategic Concept, 7 July 2009, available online: http://www.nato. int/cps/en/natolive/news 56326.htm?, 2009-11-28

${ }^{3}$ Albright M., "NATO 2009: Past Lessons, Future Prospects", http://www.nato.int/cps/en/natolive/opinions_56158.htm, 2009-11-29.
} 
and withdrew most of their troops from Europe, and Russia has become a fulltime player in Euroatlantic security affairs.

Lord George Robertson (NATO secretary general from 1999-2004) had offered another widely overused slogan for NATO's future destiny: NATO had to "go out of area or out of business". Today, however, some analysts quip that after going out of area to Afghanistan, NATO might be dangerously close to going out of business. ${ }^{4}$

NATO is quite clearly suffering from a communication problem. NATO is not a prominent fixture in the Western news media. Probably the most visible aspect of NATO is its operation in Afghanistan. NATO usually gets credit for being a complementary, if not always forthcoming and helpful part of the American effort to stabilize and reconstruct the country. The spotlight is often quite negative: unwillingness of European Allies to apply lethal force and reluctance to contribute some advanced (and pricey) capabilities, like helicopters are emphasized. When the Allies do apply the air power, the media trump up civilian casualties.

Being "out of area" also means being "out of sight" for the general public, especially in the case of smaller Allies that do not host global TV networks. CNN or BBC do not broadcast the daily lifes and adventures of Czech or Lithuanian troops in Afghanistan. And even if they did, most Lithuanians would not watch it anyway. Basically, it is an unwinnable uphill battle for "hearts and minds" at home, not only in the areas of operations. The only other element that gives NATO some regular publicity (for better or worse) is Russia's loathing of the Alliance for its conspiratory encroaching upon Russia's self-delineated sphere of legitimate interests.

It is no doubt that NATO's public face and make-up is changing. With addition of 12 East-Central and Southern European countries NATO has become a more diverse and, quite literally, more youthful organization (most Ambassadors from the newer Allies at the North Atlantic Council tend to be younger than their Western counterparts).

A new generation of leaders is emerging with little memory of the darkest Cold War days. Barrack Obama was still a student and a "community organizer" and Nicolas Sarkozy and Angela Merkel were just starting their political careers in the 1980s, when the Cold War started to unravel. They matured into statesmen and leaders during the years when history was put on hold to reap the peace dividends. Their background no doubt shaped their political views, instilling them with the values of pragmatism, openness, dialogue and cooperation rather than ideology, isolation, confrontation and paranoia of the Cold war era. The results of this change are already evident and France's return to NATO's integrated military structure after 40 years of absence tops the list.

At the same time, the North Atlantic Council still remains an exclusive club of elderly, white, graying, upper-class male statesmen. Females and non-Caucasian males are a extreme rarity in this circle (to say nothing about

${ }^{4}$ See, for example: Patrick S.M., “Out of Area, Out of Business?”, National Interest Online, 25 March 2009. 
the top job of the Secretary General). One could argue that on a very basic, anthropological level, this subjective fact does limit the worldview of this body at a time when the nature of the global politics is in a constant flux. In broader theoretical terms, NATO could still be described as a very state-centric organization, which functions on the basis of such classical notions as territory, sovereignty and military power. In that sense, it is still an organization of the $20^{\text {th }}$ century geopolitics. The Afghanistan experience is no doubt changing that reality, albeit slowly. Rapid advances of technology and uncontrolled forces of globalization are giving rise to mobile, politically conscious and assertive global community which is transcending the state-centric politics. Sooner rather than later the Allies will have to grasp this new reality.

A simple comparison of NATO's logo for the $60^{\text {th }}$ anniversary with the logo of the Russian Federation Mission to NATO should amplify the case for this apparent crisis of ideas.
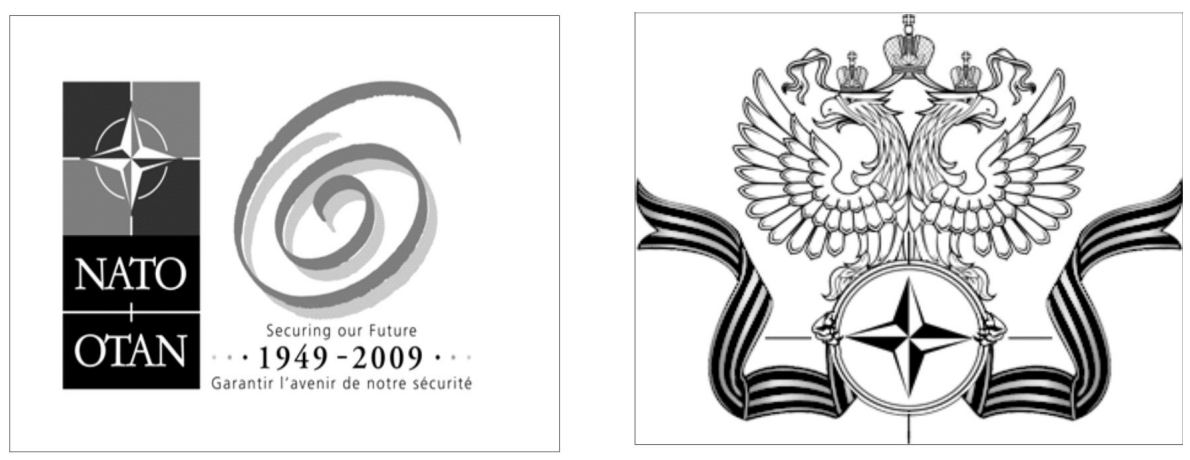

Figure 1. NATO's crisis of ideas

NATO seems to be lost in transformation, while the symbology of its Russian partner radiates full confidence and control of its goals and policies.

\subsection{Strategic dissonance}

One could argue that NATO is struggling with a strategic dissonance (see Figure 1), which emanates from the confluence of what Robert Cooper calls pre-modern, modern, and postmodern states. ${ }^{5}$

Most Allied nations could be considered "postmodern" societies, which are affluent, secular and emancipated. Borders, national sovereignty, military power are no longer the defining elements of the domestic political discourse, especially in Western Europe, but increasingly elsewhere too. People are more preoccupied with the prosperity of their households and security on the stre-

${ }^{5}$ See: Cooper R., The Post-modern state and the World Order, London, Demos, 1996. 
ets of their hometowns rather than the number of tanks or nuclear missiles in the possession of a hostile superpower, as was the case during the Cold War. These are post-national, post-sovereign and post-territorial communities, for whom the concepts of "national borders" and "national interest" are becoming obscure memories of the past.

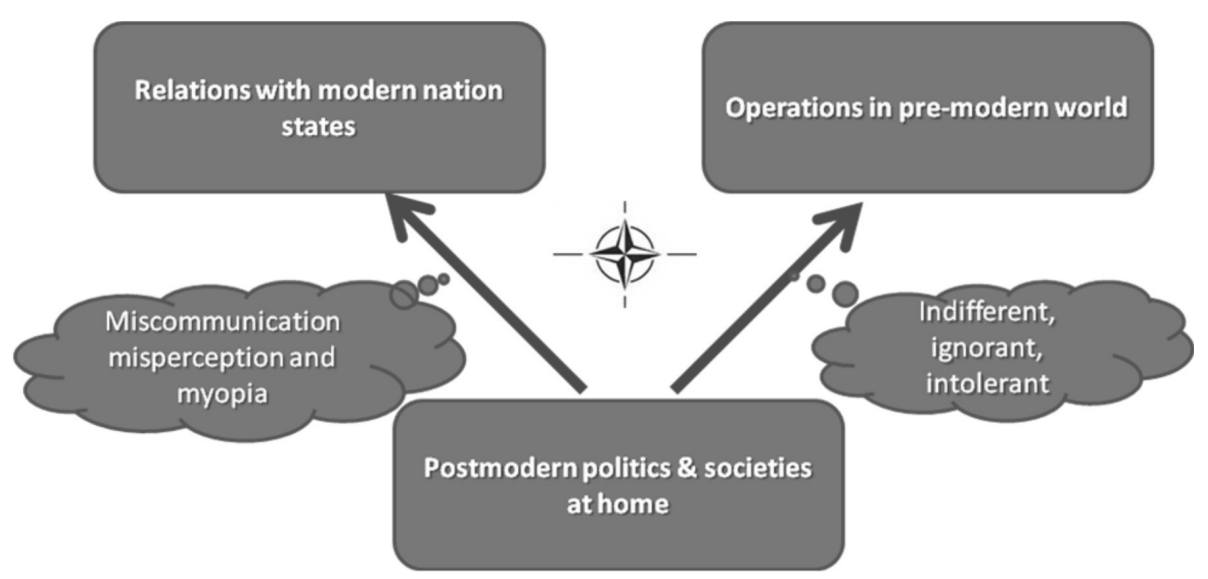

Figure 2. NATO and the strategic dissonance.

However, this is not the case in many modern nation states, starting with the "BRIC" countries and, indeed, most of the world outside Europe and North America. This is the world in which the rules of $20^{\text {th }}$ and even $19^{\text {th }}$ century still apply: a centralized national state, usually built around one main ethnicity, is the central element of life for the citizenry. In the domestic politics, citizens are subdued and serve the state objectives. State interest is far above that of an individual interest. In international affairs, the security dilemma dictates the logic of zero-sum game and perpetual search for balance of power.

Finally, there are spots of pre-modern spaces on the world map, mostly in places where the project of national statehood has failed soon after the end of the colonial era. The central government is either very weak or non-existent altogether. Domestic politics are organized around warring factions and/or tribes. Human dignity and life has little value, to say nothing about basic human rights. Today, the most extreme such example is Somalia, but Afghanistan with its tribal approach to politics and almost genetic immunity to Western-style democracy could also be considered a pre-modern space.

The encounters among postmodern communities and modern nation states produce misperceptions and miscommunication akin to the one constantly re-occurring between, for example, NATO and Russia, EU and Russia or EU and China. The starting point for these encounters could hardly be more disparate for the sides involved. Countries like Russia and China pursue vigorously "national interests" as defined by the political elites whose accountability to their publics is limited to maintaining minimal living standard. Any public 
quest for alternative arrangements is pretty much outlawed. The key "national" interest for these elites is the survival of the ruling regime by any means necessary. The central premise of action for the North American and European decision makers is democratic legitimacy and public good, for only this premise can help their re-election. This is distinction is of paramount significance and cannot be merely glossed over by the rhetoric of "mutual interest" - while both sides can be interested in the same object, issue or problem, the nature of the interest itself will be inherently different.

Engagements in pre-modern space by Western states present a different kind of challenge. When national defence matters have descended way down on the list of national priorities in most Western countries after the end of the Cold War, political, military and industrial elites came up with the idea of RMA - Revolution in Military Affairs. The RMA promised a heave reliance on advanced technology in the modern battlefields, making human casualties much rarer than during the bloody conventional wars of the $20^{\text {th }}$ century. NATO on its own part responded with the idea of defence "transformation", which meant the shift from armour-heavy, territorially organized conscript armies towards much lighter, mobile, well-equipped and deployable professional units, fit for expeditionary operations far beyond Alliance's border. The only problem with this entire endeavor was the public buy-in. The $9 / 11$ provided the necessary legitimacy and rationale for the international operation in Afghanistan. 8 years later, however, Western societies are growing increasingly intolerant to the rising number of casualties, ignorant about the causes of the Allied presence in Afghanistan, or other such places, and often indifferent about the welfare of the people their troops are trying to improve, while putting their lives in danger.

\section{Which raison d'etre?}

A good strategy should entail coherent and consistent employment of available means in efficient ways to achieve definite aims. For the new Strategic Concept of NATO to work, it should be explicit about its core purpose, just as it was in the previous iterations. Unti at least $9 / 11$, the core purpose of NATO was uncontroversial - collective defence of NATO's territory and population against an attack of a conventional, near-peer enemy, in the past epitomized by the Soviet threat. 9/11, however, ruined the strategic imagination of the Allied planners and redefined the type of attacks that the Allies should anticipate in the future. It has been assumed that to prevent such attacks, the collective defence of NATO must start at the Hindu Kush rather than NATO-Russian borders. The crux of the issue is this: is it possible to reconcile NATO's historic raison d'etre of defending NATO's territory with the newly discovered sense of duty to build peace, security and prosperity in places as far away from Allied territories as Afghanistan or Horn of Africa? 


\subsection{Afghanistan, and beyond}

NATO's gargantuan effort in Afghanistan seems to be defining the Alliance more than anything else. As of winter 2009, NATO Allies were stuck in Afghanistan, with rather bleak prospect for a successful exit. The war in Afghanistan is variously labeled the "forgotten war" and the "un-winnable war". On $7^{\text {th }}$ October 2009, the war turned 8 years old, counting from the beginning of "Enduring Freedom" operation, which was soon overshadowed by the "Iraqi freedom" (hence "the forgotten"). NATO started to take charge of the entire country in 2003, and the end to the war is still nowhere in sight (hence "the un-winnable"). And yet, the ISAF mission is what defines NATO of the $21^{\text {st }}$ century, for better or worse. All 28 Allies are fully committed to this common cause, including through troops and/or civilian experts. A number of partner countries ( 15 in all) is on board, bringing the total number of troops to some 71 000, supported by (or supporting) 94000 Afghan National Army personnel. ${ }^{6}$ NATO is working, cooperating (and sometimes even coordinating) its activities with a number of international organizations, primarily the UNAMA and the $\mathrm{EU}$, and a myriad of various non-governmental outfits. The very nature of the operation is remarkable in several respects: it was initially conceived as a NATO response to the 9/11 attacks on the US soil, so basically as an Article-5 type of operation, i.e. defence of the Alliance territory and population. However, it has quickly evolved into a massive security, stabilization, reconstruction, training, development and even nation-building effort, taking place in a hostile environment, very far away from the Alliance border's (unlike another major NATO's endeavor in the Balkans).

The NATO leadership itself considers Afghanistan as a crucial test of the organisation's political viability and military credibility. George L. Robertson has famously proclaimed that NATO needs to go to Afghanistan, or else Afghanistan will come to NATO. The Declaration on Alliance Security clearly states Afghanistan to be NATO's "key priority". The former Secretary General Jaap de Hoop Scheffer was persistently repeating that NATO's credibility is at stake in Afghanistan throughout his term in office. With the benefit of hindsight, it may yet turn out to be quite a costly stake.

On the one hand, the Afghanistan operation clearly gave NATO a new life after it has sorted out the Balkans. No less importantly, it also keeps Alliance's name in the news headlines. Even if the media coverage tends to focus on the negatives (civilian casualties, failure to stem drug production, fraudulent Presidential election in the summer 2009, growing number of suicide attacks etc.), the occasional spotlight saves NATO from the complete oblivion in the eyes of the internet generation, which is coming of age and becoming the main group of tax-payers, upon which, ultimately, all defence budgets of all Allies will depend. On the other hand, framing ISAF in fatalistic terms of "make or

\footnotetext{
${ }^{6}$ Official information on NATO website (as of 22-10-2009): http://www.nato.int/isaf/docu/epub/pdf/ isaf_placemat.pdf
} 
break" may indeed endanger Alliance's long-term credibility because neither Afghanistan nor any similar future endeavor will not be concluded by a simple "victory" or "defeat", but rather an indefinite sustained commitment.

Yet, one could also argue that to some extent NATO is in a league of its own, whatever the long-term outcome of its presence in Afghanistan - no other international organisation can deploy and sustain so many troops over such a long period of time at such a distance, and for such a complex civilmilitary mission.

Profound NATO's commitment in Afghanistan stands in quite a contrast to what NATO was unable, incapable or unwilling to do in other parts of the world, including on its periphery. The Iraq war stands out as one of the most divisive moments in Alliance's history. The lowest point was reached in the wake of America's invasion, when NATO has wavered at Turkey's request for precautionary reinforcement of Turkey's defences. While the transatlantic rift has mostly healed, and NATO has been running its own small training mission in Iraq since 2004, the Turkish episode left a lingering stain on the credibility of commitment to mutual defence among all Allies.

NATO has been all but absent from all the other conflicts in the Middle Eastern quagmire, despite the region's proximity. NATO, despite being, among other things, a nuclear alliance, has not been involved in any meaningful way in resolving Iran's nuclear riddle. Notwithstanding the efforts to nurture a wide variety of partnerships, including through the Istanbul Cooperation Initiative and the Mediterranean Dialogue, NATO has been a non-factor in Israeli conflicts with its Arab neighbors and the non-state militant outfits, primarily Hamas in Palestine and Hezbollah in Lebanon. Such NATO absentia from a region, which constitutes a quintessential element in the puzzle of global security, is puzzling indeed.

While Israel, at least, is not part of the Euro-Atlantic Partnership Council, the Russian Federation and Georgia both have enjoyed special and even institutionalized partnerships with NATO - a fact that did nothing to prevent a war between the two. Paradoxically, that same fact may have something to do with the origins of that conflict.

\subsection{Russia: cumbersome, but indispensable}

Russia is still to a large extent what Robert Cooper would call a modern nation-state (with some of its regions, primarily North Caucasus, plunging back to anarchical, pre-modern sate). Compared to the European Union - an increasingly post-modern, post-sovereign and post-national space - NATO, a political-military alliance with strong roots in the $20^{\text {th }}$ century power politics, would seem to be better placed to understand, cooperate and confront Russia, as necessary. However, the inner tension within the Alliance between the transformation urge and traditional security needs, all but eliminates this advantage. As a result, the Alliance quite simply does not have a coherent Russia policy, 
and can only pursue a cumbersome relationship of "one step forward, two steps back". This tension was most visibly exposed by the war in Georgia. ${ }^{7}$

NATO went out of its way to declare "no business as usual" after Russia's military invasion into Georgia on 08/08/08, only to de facto recognize the new reality on the ground a few months later by going back to "normal business" and even "new beginning". ${ }^{8}$ The conflict took place between two Partners of NATO: a country that is a member of a joint format (NATO-Russia Council) and a country, which was promised membership in NATO at the Bucharest Summit in 2008. The latter fact did not prevent Georgia from foolishly buying into Russian provocations, and the former fact did little to moderate Russia's brutal response and subsequent occupation of parts of Georgia proper. In the end of the day, it was the French President and the EU that helped bring the armed conflict to an end, not NATO. As if to add insult to the injury, in September 2008 NATO has stumbled upon a serious breach of Alliance's security of information, when a high-ranking Estonian defence official was apprehended for supplying classified NATO documents to the Russians. In a commendable if belated exercise of facesaving, NATO expelled two Russian spies on the occasion of the resumption of NATO-Russia Council meetings in the end of April 2009. ${ }^{9}$

The Soviet Union defined NATO's raison d'etre during the Cold War. Today, Russia still remains an extremely important feature, shaping the Alliance's identity. First, a number of Allies, especially those on the eastern side of Europe, harbor various real and imagined security concerns, as well as historic grievances, towards increasingly assertive, revisionist Russia. Those include energy security, cyber security, political and economic meddling, and after Georgia, even military security concerns. These insecurities were clearly manifested by a recent "open letter to President Obama" from prominent Central and Eastern European figures. ${ }^{10}$ Second, while most Western European Allies do not necessarily share these concerns, they also struggle to build a lasting constructive partnership without recurring surprises of energy cut-offs, highprofile assassinations, unpredictable economic climate for Western businesses inside Russia, and Russia's constant political and now also military meddling in Europe's Eastern neighborhood. Third, the NATO-Russia relationship is truly reciprocal - Russia is one of the very few countries outside NATO that pay very close attention to every action, reaction or statement by NATO. All too often, it is the rather frequent and mostly negative statements by Russian officials that define NATO in the eyes of the public. This is not a bad thing per se, as long as it helps keep NATO in the headlines.

\footnotetext{
${ }^{7}$ Erlanger S., "West is struggling to unite on Georgia", International Herald Tribune, 2008-08-18.

${ }^{8}$ See "NATO and Russia: A New Beginning", speech by NATO Secretary General Anders Fogh Rasmussen at the Carnegie Endowment, Brussels, 18 september, 2009, http://www.nato.int/cps/en/natolive/ opinions 57640.htm, 20100520.

${ }^{9}$ Barber T., "Russians expelled in NATO spy storm", Financial Times, April 30, 2009.

${ }^{10}$ See: "An Open Letter to the Obama Administration from Central and Eastern Europe", Gazeta Wyborcza. pl, 200907 15, http://wyborcza.pl/1,75477,6825987,An_Open_Letter_to_the_Obama_Administration_ from_Central.html, 20100520.
} 
The Economist has recently argued that "the Russians may already have achieved much of what they want", namely, halting NATO enlargement and the plans for a missile defence site in the Eastern Europe. ${ }^{11}$ That assertion clearly assumes that Russia does have an articulated strategy vis a vis NATO and the United States. It is much less clear whether the same could be said about the Allies. Indeed, there is a quite glaring lack of a coordinated approach, not to mention strategy, on Russia. Passages devoted to the partnership with Russia in the most recent NATO communiqués are usually rather cumbersome ones, a mixture of great expectation and belief in amazing potential on one hand, and cautious rollicking for unfulfilled commitments with regard to Georgia and feet dragging over such issues as the Treaty on the Conventional Forces Europe (the CFE - Russia suspended its participation in the summer 2007). The banal explanation for this mish-mash approach is the differences in viewpoint between the Allies who used to be on the West side of the Iron Curtain and those who are still labeled "ex-communist" countries by the Western press (not so much by the Eastern European press though). One can also assume that this division is well understood, appreciated and further exacerbated by the decision makers in Moscow.

The popular logic behind the "strategic importance" of NATO-Russia cooperation is twofold. First, political dialogue is a value in itself, which should help build mutual trust and confidence, and (sometimes) avoid conflicts. Although this relationship was launched in 1997, and further reinforced by signing the Rome declaration, establishing NATO-Russia Council in 2002, the new Russian security strategy, adopted in 2009 , is very explicit about naming NATO a security threat to Russia. So much for the trust and confidence building. As for conflict prevention, no frozen conflicts in the mutual neighbourhood were resolved via the $\mathrm{NRC}$, and one frozen conflict burst into open combat despite the NRC. The second popular reason behind the illusion of NRC cooperation is the fight against common security challenges - first and foremost terrorism and proliferation. In the case of the latter, Russia is more of a liability than help, with Iran being point in case. As for terrorism, a couple of Russian vessels did take part in NATO anti-terrorist operation in the Mediterranean for a few weeks over the last 5 years. And Russia has granted transit non-military supplies to NATO forces in Afghanistan, while at the same time worked to obstruct such transit through Kyrgyzstan. At the same time, Russia failed to gain Western acknowledgment that its violent crackdown on Chechnya was an entirely anti-terrorist operation, albeit atrocities of Chechen separatists (like the one in Beslan school in 2006) did earn some sympathy for the Russian version of the Chechen tragedy.

NATO enlargement has been an implicit element of NATO-Russia relationship ever since the fall of the Berlin wall. In December 1996, to assuage Russia, NATO unilaterally declared that enlarging the Alliance would not require a change in its nuclear posture and, therefore, NATO has "no intenti-

11 "A new balance in Europe", The Economist, 21 Nov 2009, p. 36. 
on, no plan, and no reason to deploy nuclear weapons on the territory of new member countries". ${ }^{12}$ The 1997 NATO-Russia founding act, which established the Permanent Joint Council, contained a clause wherein NATO has pledged to refrain from "additional permanent stationing of substantial combat forces" ${ }^{13}$ These provisions helped Russia to swallow the first batch of former Warsaw pact allies - Poland, Czech Republic and Hungary acceding NATO. Creation of the NATO-Russia Council, in which all countries participate as equals and which makes decisions by consensus, was one of the crucial stepping stones towards the 2004 enlargement round, that brought another 7 Central and Eastern European countries into NATO.

However, despite the pathos of the Rome Declaration which promised "a new quality", the relationship has soured gradually: first, Russia abruptly suspended its participation in the CFE, which was hitherto considered "the cornerstone of European security". The relationship reached a freezing point after the 2008 August war. Georgia's and Ukraine's movement towards NATO membership played a major part in this deterioration. The idea of the "new security architecture for Europe", put forward by the Russian President D. Medvedev in June 2008 and quite actively promoted ever since might be considered as the groundwork for another "quid pro quo" type solution that preceded the first two contentious enlargement rounds.

It all ties back into the question of NATO's identity: how far and, no less importantly, why NATO could or should expand any further? Who can and cannot become NATO members? And why the number of Allies nearly doubled after the Cold War, which was its raison d'etre in the first place? The primary source - Article 10 of the North Atlantic Treaty - states that the Allies "may, by unanimous agreement, invite any other European State in a position to further the principles of this Treaty and to contribute to the security of the North Atlantic area to accede to this Treaty". So, in theory, both Ukraine and Georgia should be considered eligible future members (as was recognised by NATO itself during the Bucharest Summit) if they are "in a position to contribute to the security of the North Atlantic area". As in the case of the first two enlargement rounds, the argument again boils down to this: will accession of new members despite Russia's objections enhance or undermine Euroatlantic security? The two precedents prompt towards a positive answer. However, the lack of political and public consensus in Ukraine, and Georgia's territorial problems make both cases questionable. Nevertheless, it is also clear that the decision to open the "open doors" of NATO to new members is a political one: if all Allies agree that a country is worthy to join the treaty, it will happen, regardless of the country's "position to contribute".

\footnotetext{
${ }^{12}$ NATO's Nuclear Forces in the New Security Environment, available online: http://www.nato.int/issues/ nuclear/sec-environment.html

${ }^{13}$ Founding Act on Mutual Relations, Cooperation and Security between NATO and the Russian Federation signed in Paris, France, 27 May 1997, availabe online:

http://www.nato.int/cps/en/natolive/official_texts_25468.htm
} 


\section{A common-sense NATO}

NATO's difficult quest for stabilization and reconstruction in Afghanistan and indecision about its policy vis a vis Russia prompts to the need for the Alliance to go back and reconsider its grass-roots and re-address a number of core conceptual dilemmas. For NATO to remain "the most successful alliance in history", it should not allow the outside factors to define its role in the world, but rather opt for a simple "NATO first" principle, which would entail answering simple question of what NATO could, should and would be able to do in the dynamic security environment of the $21^{\text {st }}$ century?

\subsection{A regional military block vs. a global political Alliance}

The Cold War NATO in a sense was a boring organization. It had a singularly clear purpose: deter, and, if deterrence fails, defend against the Soviet conventional and nuclear onslaught. The Washington Treaty defined its area of operations in quite rigid terms: in the Treaty's preamble, the Allies committed to "seek to promote stability and well-being in the North Atlantic area", meaning NATO-Europe and North America. Its military purpose of collective defence trumped its political role and utility as a platform for political consensus-building. Although NATO did embody the transatlantic link, it did not prevent both sides of the Atlantic from pursuing quite different and sometimes even conflicting political approaches towards the Soviet Union. For example, the purpose and logic of the American "containment" doctrine or even the concept of "détente" was of quite different nature than the Ostpolitik, which basically accepted the new status quo in Europe.

NATO's military structures were geared towards one total war. The Allied armies were massive, based on conscription, and organized into heavilyarmoured divisions. At the spearhead of the potential conflict with the Russkies was the Allied Command Europe Mobile Force (AMF), which was "organised into various pre-planned, multinational force packages optimised for deployment" to five contingency areas in the Northern and Southern Europe. ${ }^{14}$ The somewhat scary logic behind this force was to ensure that there are as many as possible different national flags on the first coffins returning from the front line of the Third World War, so as to ensure that no Ally will be able to defect from the collective defence commitment. The United States permanently kept some 200000 forces in Europe, most of them in the West Germany - the central battleground of the "worst case" scenario. A formidable nuclear umbrella provided by the Americans to the rest of the Alliance made sure that the cost of that "worst case" scenario would be unbearable even to the most reckless Soviet leadership.

${ }^{14}$ More on AMF, see: Palmer D.R., "From AMF to NRF", NATO Review, March 2009 
All that MAD ("mutually assured destruction") logic collapsed together with the Berlin wall. NATO has been "transforming" ever since, with transformation often perceived as a process rather than a destination. Some of the key dilemmas NATO continues to grapple with are presented in the Table 1 bellow.

\begin{tabular}{|c|c|c|}
\hline THE COLD WAR NATO & VS & THE $21^{\text {st }}$ CENTURY NATO? \\
\hline REGIONAL BLOCK & & DAL NATO \\
\hline MILITARY ALLIANCE & & LITICAL FORUM \\
\hline WARFIGHTING & & MPREHENSIVE APPROACH \\
\hline MOST DEMANDING OPERATIONS & & ST LIKELY OPERATIONS \\
\hline HEAVY ARMOUR, CONSCRIPT ARM & & PEDITIONARY FORCES \\
\hline
\end{tabular}

\section{Table 1. NATO's dilemmas}

NATO has clearly gone "out of area" - first to the Balkans, than Afghanistan and Iraq (with a modest training mission) and, most recently, the Horn of Africa. It has an even more impressive network of partnerships: the Euroatlantic partnership council (EAPC) encompassing 22 Partners, the Mediterranean Dialogue (7 countries), the Istanbul Cooperation Initiative (4 Gulf countries), the format involving the non-NATO ISAF contributors, NATO-Russia Council, NATO-Ukraine Commission, NATO-Georgia Commission, and bilateral relationships with the so-called "Contact Countries" as distant from the Atlantic as Australia, Japan, South Korea and New Zealand.

Yet, it is definitely not a global policeman and hardly aspires to be one. Apart from the Afghan endeavour, NATO is not present in many other hotspots of the world. Furthermore, there is something wrong with the overall framework of the Alliance's partnership framework. Sweden and Finland, which are probably more NATO-interoperable than some of the NATO members and are significant contributors to NATO operations are treated the same way as other EAPC members, like Turkmenistan, Uzbekistan, Tajikistan, Armenia or Belarus - countries with very dubious record of human rights and extremely meager democratic credentials. The above mentioned Contact countries, which "share similar strategic concerns and key Alliance values"15 and have more in common with NATO than a few formal Partners, have yet to receive a more meaningful and long overdue acknowledgment.

NATO institutional partnerships with other key international bodies -

${ }^{15}$ Official information on the NATO website, "NATO's relations with Contact Countries", http://www.nato. int/cps/en/SID-B1F50273-84ED580F/natolive/topics_49188.htm, 2009-12-08 
the United Nations and the European Union - have become the staff of lore. Despite a long record of practical cooperation, only in September, NATO and the UN managed to work out a formal "framework for expanded consultation and cooperation". The relationship with the European Union, which has an overlapping membership of 19 nations, no less, has been described in terms of a "frozen conflict" by the former NATO Secretary General Jaap de Hoop Scheffer. ${ }^{16}$ To sum up, NATO is no longer just a regional block, but neither has it become a truly global NATO. More importantly, the new Strategic Concept will hopefully streamline and rationalise the expanding NATO partnerships network and clarify what meaningful purpose this network should serve.

The numerous cooperation and dialogue frameworks that NATO has launched allows to contend that it is much less military and much more political Alliance than it used to be during the Cold War. At the same time, one could argue that NATO's political power has stemmed from its military prowess. Today, however, military power is no longer the sole or the most important determinant of the world affairs. Increasingly interdependent global economy, competition over energy and other vital resources, climate change, changing demographic face of the Western societies, the exponential growth of importance (as well as vulnerability) of cyberspace in daily life, are key some of the key features of contemporary international politics. While NATO's military superiority is unrivalled and will remain so in the foreseeable future, to avoid the deflation of its political role and remain relevant, NATO had to take note of these new dynamics.

\subsection{From war-fighting to "comprehensive approach"?}

While NATO, ostensibly, still remains about security of the Allies (and not, for example. creation of economic welfare), the question is which threats and challenges it should address? The Comprehensive Political Guidance (CPG) (a sort of an interim update to the Strategic Concept, adopted in 2006) highlights to principle threats - terrorism and weapons of mass destruction. This classification, however, has some implicit theological problems. In European mindset, terrorism is pretty much a business for police and judiciary system. George W. Bush's "war on terror" by means of military force has lead to the Iraqi quagmire. A more legitimate front of that "war on terror" - Afghanistan, is more reminiscent of an asymmetrical guerilla conflict, although the opposing force does use terrorist methods. In any case, it would be an awkward task to paint NATO - a military alliance - as a global anti-terrorist police force.

As for the second threat - proliferation of WMD - again, NATO's record is extremely meager. Operation Active Endeavour is the most visible and probably the only clear-cut effort in that regard. As it was argued above, NATO is

\footnotetext{
${ }^{16}$ Jaap de Hoop Scheffer "NATO and the EU: Time for a New Chapter", 29 Jan 2007, available online: http://www.nato.int/docu/speech/2007/s070129b.html, 2009-12-08.
} 
nowhere to be seen on the dossiers of key proliferators, such as North Korea or Iran. Moreover, the Allies do not even have a common policy on nuclear nonproliferation and disarmament issues. They do not coordinate their positions on the NPT (the Nuclear Non-proliferation Treaty). In the UN, some Allies vote in favour of nuclear policy-related UN resolutions that may undermine the agreed official NATO's nuclear policy.

Energy security is another high profile dossier. The CPG mentions the "disruption of the flow of vital resources" as one of the key challenges for the Alliance. While NATO's subsequent public declarations hints at some steps undertaken to bolster its role in energy security matters, there is objectively little a political-military alliance can do about an essentially political-economic problem. Developing rapid response energy security brigades to dissuade the major energy suppliers from using gas cut-offs as a political weapon is hardly a serious option.

Not surprisingly, the CPG stipulates that "collective defence will remain the core purpose of the Alliance", but caveats this statement with a notion that "the character of potential Article 5 challenges is continuing to evolve". It is not entirely clear what this implies in practice. For example, some Allies (most notably Estonia in 2007) have experienced quite extensive cyber attacks in the past few years. Just like energy cut-offs, such security challenges can severely threaten and even breach social, economic and financial integrity and stability of the Allies, and in that sense, probably fits the description of an "evolving character of potential Article 5 threats". However, it is unlikely that they could evoke activation of Article, let alone the use of military force to counter challenges of completely different nature. Again, the new Strategic Concept should provide more clarity on this issue.

NATO may well have to stick to the well-trodden approach in the new Strategic Concept, reiterating the collective defence as the core purpose of the Alliance. Secondly, the Allies will likely re-state once again that NATO is not against anybody, but in favour of world-wide peace, security, stability, security and prosperity, leaving the question of boundaries of NATO's possible area of action an ambivalent "wherever needed and called upon".

Even if the common sense dictates that NATO should maintain its focus on what it does best - defence planning and military action, the nature of contemporary military engagements has been changing dramatically, as showcased by the Iraq and Afghanistan experiences.

The United States-led coalition in Iraq and NATO in Afghanistan have learned the hard way that military superiority alone is not enough - political reconciliation among the warring factions and economic development and reconstruction are probably even more important, because they address the root causes of the conflict. Success in a quagmire like Afghanistan requires both a concerted decision making of different international organizations and a coordinated civilian-military action on the ground. Yet, 8 years into the campaign, NATO is still struggling with the concept of the so-called "comprehensive approach", for a number of reasons. First, most international organi- 
zations like to "coordinate" but do not like to be coordinated. For example, the UN considers itself the most important organization in Afghanistan, despite the fact that the Allies carry by far the biggest burden. Second, the Allies are undecided whether NATO should develop its own civilian capabilities, or depend for those on organizations like the European Union, despite the fact that NATO already runs a number of provincial reconstruction teams (PRTs), which do exactly that - coordinated civilian-military efforts of stabilization and reconstruction. Finally, each country leading a PRT in Afghanistan runs its own little experiment of "comprehensive approach" with little or no coordination at the national level. As a result, there are a lot of "comprehensive approaches" without a single agreed NATO policy.

In a sense, the expectations placed upon NATO's forces are more complex than ever. They are supposed to be extremely professional and well-versed in advanced technologies, like UAVs, precision-guided munitions and other network-enabled capabilities. They are expected to deploy on short notice at long distances with little or no host nation support. They have to be able to perform joint multinational expeditionary operations in hostile environment. They are expected to fight and help build hospitals and schools simultaneously in the same area of operations. They are no longer just soldiers, but also experts in tribal diplomacy, Islamic religion and indigenous culture. This was the basic idea behind the NATO Response Force - a 25 000-strong force capable of performing missions worldwide across the whole spectrum of missions from humanitarian aid to Article 5. NATO has declared the NRF fully operational in Riga Summit in 2006, but had to recall this decision a few months later due to repeated failures to generate the required capabilities.

NATO's level of ambition outlined in the CPG is ambitious indeed: "NATO must retain the ability to conduct the full range of its missions, from high to low intensity, placing special focus on the most likely operations, being responsive to current and future operational requirements, and still able to conduct the most demanding operations." ${ }^{\prime 17}$ This provision reflects the search for an uneasy balance between the need to focus on "most likely operations", like Afghanistan, and at the same time to retain the capacity to react to a less likely but more demanding conventional scenario.

Given the constantly persisting capability shortfalls in Afghanistan and the failure to generate the NRF, one may question whether NATO would be able to undertake another major crisis response operation simultaneously with the ongoing Afghanistan mission? The answer probably would be conditioned on the level of the US involvement. After all, many allies did take part in both ISAF and Iraqi operation, although the latter was not carried out under the NATO flag. More recently, the US draw-down in Iraq allowed Obama's administration to boost its troops presence in Afghanistan. In any case, the

${ }^{17}$ See: Comprehensive Political Guidance, Endorsed by NATO Heads of State and Government on 29 November 2006, http://www.nato.int/cps/en/SID-94B7F554-9A0B094E/natolive/official_texts_56425. htm, 2009-11-25 
tension between the political ambition and the available resources is likely to continue in the foreseeable future, because apart from a few notable exceptions (the US, France, the United Kingdom, Turkey and Greece), the defence expenditures have been flat or even decreasing in most European countries over the past few years.

An additional concern is the strategic awareness of Alliance's defence planners. The military has a notorious habit to prepare for the "last war". While today the "most likely" scenario presumes an Afghanistan-type mixture of counter-terrorism, stabilization and reconstruction effort, facing an asymmetrical and militarily inferior foe. The war in Georgia was a stark example of a different kind of war - a brief and violent inter-state encounter. NATO puts a premium on developing light expeditionary force, which is well suited for asymmetrical combat. But would this same force equally ready to fight a conventional war against a heavily-armored opponent?

Probably the only country, supported by a rag-tag collection of allies (mostly from the Central Asia) that have the potential and may have some motives to challenge militarily some of the adjacent NATO allies is Russia. By any measure, Russia would fail in a large scale conventional war against NATO. While this is all very hypothetical, two factors could somewhat complicate such a straightforward analysis. First, the question is open how fast and by what means NATO would react. Article V would probably be evoked, but the nature of the response operation would be a contentious matter. Probably the biggest unknown is whether Russia believes in NATO's solidarity when it comes to the defence of smaller and weaker neighbouring Allies.

From a Russian perspective, a rapid military incursion with limited objectives (say, on the grounds of crisis management, protection of its "citizens" and other imaginative causes) into an undefended Ally is not completely unimaginable, especially based on the Georgian example - a NATO partner, which was promised to become a member. Another X factor is Russia's nuclear doctrine, which clearly and unambiguously stipulates the possible of "first use" of a nuclear weapon even in a regional conflict, when Russian interests are threatened. And Russia happens to have a few thousands of tactical nukes, including (most probably) on its European theatre. While all this is extremely hypothetical, future developments in international politics are very difficult to forecast. Further economic downturn, disgruntlement of the military and society at large, social unrest may prompt Russian leadership to once again divert the public attention to the outside "enemies".

It is clear that the new Strategic Concept will not call upon NATO "to come home"18. At the same time, NATO should at least ponder different possibilities, however unlikely, especially if they may endanger directly Alliance's territories and population.

\footnotetext{
${ }^{18}$ Ringsmose J., Rynning S., "Come home, NATO? The Atlantic Alliance's New Strategic Concept”, DIIS Report, 2009, no 4, (Danish Institute for International Studies), http://www.diis.dk/graphics/Publications/ Reports2009/DIIS_report_200904_RingmoseRynning_NATO_web.pdf, 20100510.
} 


\section{Five Years of Membership - "Curb Your Enthusiasm?"}

The Strastbourg/Kehl summit has coincided with the $5^{\text {th }}$ membership anniversary of 7 "newer" Allies, including Lithuania. While NATO's Strasbourg communiqué was misread by some in Lithuania ${ }^{19}$, it raised a pertinent question - have Lithuania become an indispensable part of NATO and got rid of the self-perceived presence on the periphery of the Euro-Atlantic area? After all, political geography is a mental, not a material state of play.

As I have argued elsewhere, "Yesterday came suddenly" for Lithuania. ${ }^{20}$ By achieving the two greatest historic objectives - memberships in NATO and the European Union, Lithuania has lost clear strategic landmarks for the future. "Being active member of NATO and EU" - a prominent slogan in various national foreign and security policy documents of Lithuania, does not have the sense of strategic urgency, does not capture attention and does not inspire awe and admiration on behalf of the respective publics. While great historic achievements are not readily available for Lithuanian decision makers, there are more than enough challenges and dilemmas to tackle.

The 5 years of membership in both NATO and the EU brought a number of revelations. First, while Lithuania sought the Euroatlantic integration and considered NATO hard security guarantees and EU soft security guarantees as two sides of the same coin, they soon learned that both organizations are distinct and sometimes even competing defence actors, with different ambitions and different institutional set-up. In addition, both are essentially global actors with global partnerships and outreach, while Lithuania's interests and concerns are objectively confined to the Baltic region. Last but not least, Russia is seen by many in NATO and the EU as an important or even "strategic" partner, while for Vilnius it essentially remains a security problem of strategic proportions.

The drafting of the new Strategic Concept is important for Lithuania for at least two reasons. First, Lithuania was not part of NATO when the 1999 document was agreed. So, at least formally, Lithuania together with other new member states, will have a chance to shape the future of NATO. Quite paradoxically, the new concept may move NATO even further away from what Lithuania envisaged NATO would be and should be for their security. Secondly, it is an excellent opportunity for Lithuanian decision makers to engage the drafting process as an intellectual exercise of introspection, in search of a new and clear national security vision, i.e. what kind of security environment they want to live in, what threats are most acute, and what means (national or multinational) should be employed to address those threats.

\footnotetext{
${ }^{19}$ Samoškaite E., "NATO aljansui esame periferija?" [We are NATO‘s periphery?], Delf.lt, 4 April 2009 -., http://www.delfi.lt/news/daily/lithuania/article.php?id=21326605, 20100520 - in Lithuanian.

${ }^{20}$ See: Paulauskas K. "Yesterday Came Suddenly: the Brave New Security Agenda of the Baltic States", in : Tiirmaa-Klaar H., Marques T., eds, Global and regional security challenges: A Baltic Outlook, Tallinn University Press, 2006, p. 15-41.
} 
It may end up being an exercise in "curbing enthusiasm". When Lithuania was entering NATO, a number of bold defence planning assumptions were made. These assumptions underpinned a rather overwhelming defence reform program. As the comparison in the table indicates, not all of those assumptions survived the reality check so far, but the results are not all bleak.

\begin{tabular}{|l|l|}
\hline \multicolumn{1}{|c|}{$\mathbf{2 0 0 4}$ assumptions } & \multicolumn{1}{c|}{ 2009 realities } \\
\hline $\begin{array}{l}\text { Lithuanian armed forces will not fight alone }- \text { no } \\
\text { need for a large conscript army }\end{array}$ & $\begin{array}{l}\text { No NATO defence plans } \\
\text { Some informal defence plans }\end{array}$ \\
\hline $\begin{array}{l}\text { NATO deploys prior to crisis to bolster } \\
\text { deterrence }\end{array}$ & $\begin{array}{l}\text { NATO overstretched in Afghanistan, } \\
\text { NRF not operational }\end{array}$ \\
\hline $\begin{array}{l}\text { Lithuania in Afghanistan, and } \\
\text { NATO in Lithuania }\end{array}$ & Air policing continues \\
\hline No need for territorial defence & Conventional scenarios not impossible \\
\hline
\end{tabular}

\section{Table 2. Assumptions and realities of Lithuanian defence planning}

First and most importantly, steadfast credibility of collective defence commitment enshrined in the Article V of the Washington Treaty was taken for granted in Lithuania. Having secured invitation to accede NATO in 2002, Lithuanian policy makers and in particular the leadership of the defence establishment could start focusing on a vast defence transformation effort, as required by NATO defence planners. NATO collective defence implies that no Ally will be left alone to cope with a threat to its territory or population. In return, however, each Ally must accept a fair share of the burden of collective defence. Lithuania, accordingly, had to realize that membership is not about NATO's collective defence for Lithuania, but rather collective defence of the Alliance.

Building upon that logic, Lithuanian armed forces were reorganised from a large, poorly equipped, poorly trained and immobile conscript army capable of only a limited territorial defence, into a smaller but better equipped and better prepared professional force, capable to generate and deploy certain specialized capabilities to NATO operations. From 1994, Lithuania has accumulated quite a long record of participation in international operations, which culminated in the decision to take over the responsibility for an entire province in the mountainous heart of Afghanistan - Ghowr in 2005. This decision essentially epitomized the logic of "Lithuania in Afghanistan, NATO in Lithuania". Even if Afghanistan per se is not of primary importance to Lithuania's national security and defence, Afghanistan, as it was argued above, is top priority for entire NATO. Only by abiding by the principle of solidarity with other Allies Lithuania can expect that same solidarity from those Allies in case of need. In case of Lithuania, that solidarity has one clear and tangible expression - the NATO air policing mission in the Baltic States, ongoing on a $24 / 7$ basis since the accession day - 30 April 2004, and which is already scheduled to continue at least until 2014. 
On the other hand, certain security concerns persist. The war in Georgia has shown that conventional conflicts among European states cannot be deemed impossible in the future. Lithuania, together with the other Baltic States, are, at least in geographical terms, clearly exposed territories on the periphery of the Alliance, which were considered "indefensible" ${ }^{21}$ long before their accession to NATO. If one adds a host of bilateral problems these countries experience in their relations with their big neighbor, Russian leadership should probably feel some temptation to test the limits of Alliance's unity and resolve, as was demonstrated by the largest military exercises since Soviet era - Zapad and Ladoga, which took place in the immediate proximity of the Baltic States in the fall 2009. The Baltics themselves have long questioned whether collective defence guarantees can be credible without a clear contingency plan - these doubts have finally been heeded to some extent in the form of a generic informal defence plan, which was presented to the three countries in December 200922, partially due to Russia's recent military adventurism.

All in all, the record after 5 years of membership is mixed. Lithuania has come a long way in transforming its security thinking, its armed forces and its performance within the Alliance. It did learn to annoy some other Allies over such issues as Russia, energy security or Ukraine's and Georgia's infamously bumpy path to NATO. It is also quite capable at aligning its position to that of more powerful Allies - mostly the United States and the United Kingdom. Although Lithuanian defence planners are not always sold on the "expeditionary" philosophy of their Anglo-Saxon Allies, that philosophy at least envisages a strong and efficient NATO, while for some much more reluctant Western European allies NATO's predicament has probably served its purpose. When the opportunities for annoying or aligning are exacerbated, Lithuania is left little choice but to acquiesce to the emerging consensus.

Lithuania has yet master a more positive "Yes, we can" approach and learn how to get its interests onto NATO agenda and become more of a subject than mere object of NATO's decisions. For example, not a single Lithuanian (or Baltic for that matter) national in 5 years of membership have succeeded in the selection process for A-grade (i.e. policy-related) positions in the NATO international staff. While selection of top officials is a political and sometimes highly politicized matter (as in the case of Turkish bargain for top positions in return for support for Danish candidate as the next Secretary General), the lower ranks are supposedly open to competition to all Allies. However, distribution of posts is to some extent a reflection of Allies' comparative political weight, as well as an instrument of indirect influence upon decision shaping within NATO's bureaucracy. In the Baltic case, that weight seems to linger below significant.

\footnotetext{
${ }^{21}$ See, for example: Dalsjo R. "Are the Baltics defensible? On the utility of and prospects for a capability for self-defence", RUSI Journal, London, 1998.

22 "Disquiet on the eastern front", The Economist, 28 Nov 2009, p. 37.
} 


\section{Conclusions}

NATO is not ready to ponder retirement yet, nor should it do so. Global ambitions, built upon overstretched resources and lackluster public support cannot be sustained for a long period of time. The Alliance may have to make a choice (rather than "to find a balance") about its future purpose. One alternative is to remain a unique military organization ready for any contingency that requires robust, modern combat forces capable of surgical expeditionary interventions at short notice anywhere in the world. The alternative is a global multifaceted (and, therefore, often fragmented) forum for political dialogue and occasional action with multiple tasks, such as humanitarian aid, political consultations with any number of countries and organizations and undertaking various civil-military operations. Currently NATO seems to be stuck between the two alternatives. The danger is that by trying to do both NATO may fail at either, unless the Allied political leadership would throw considerably more resources and political will in support of NATO's endeavors.

Engagement in Afghanistan seems to be the defining moment for the Alliance. NATO's leadership has even staked NATO's future relevance on the success in Afghanistan. In addition, NATO runs an anti-piracy operation off the Horn of Africa, patrols the Mediterranean to stop proliferation of WMD, keeps the peace in Kosovo and trains forces in Iraq. On the other hand, NATO has not been present in the resolution of other major crises that took place recently - the renewed fighting Gaza or the war in Georgia. Iranian and North Korean problems are also being dealt with in other forums. While the 1999 Strategic Concept called NATO as THE forum for transatlantic political dialogue, NATO did not make its position (if any) clear and public on many of these matters, to say nothing about appropriate actions.

And yet NATO does stand out head and shoulders above other aspiring security organizations. No other institution or organization was ready or able to sort out the Balkan mess until NATO has intervened in the form of SFOR in Bosnia and Herzegovina (there is some anecdotal evidence that the US has deliberately allowed the Europeans to fail in the Balkans to teach them a lesson of humility and the indispensability of American presence in European security affairs). Only NATO had enough will and firepower to stop what was then still Yugoslavia from continuing bloodshed in Kosovo. Finally, today only NATO is capable to carry out an operation as complex as ISAF.

The spectrum of Alliance's missions and partnerships has expanded impressively since the end of the Cold War. NATO today is more global and more political, as opposed to its primarily regional and military predicament of the past. At the same time, the mantra of NATO's transformation may be masking a certain loss of direction, if not the degradation of its former political and military stature and prowess. To remain relevant in the dynamic security environment, NATO has been ponder ever news, such as energy security or cyber defence. However, at a closer examination, they do not fit easily with the traditional "core purposes" of collective defence and crisis response. 
If the older members of the Alliance suffer from the "enlargement fatigue", the newer members have started to exhibit disillusionment and waning enthusiasm. However, one should expect that the teenaged democracies like Lithuania will soon mature into full-fledged and indispensable Allies. Arguably, Lithuania is already carrying its fair share of burden in NATO's operations, which should be translated into a more considerable political weight in Brussels, not only Chaghcharan.

In the end of the day, one could argue that NATO is still first and foremost about security and defence of Allies, whatever that means for different capitals. While NATO continues to adapt and reinvent itself in order to prepare for the future challenges, it should make sure that this simple, but essential premise does not get lost in transformation. 